\title{
Pendidikan Karakter Preskpektif Ibnu Khaldun: Suatu Kebutuhan Generasi Milenial di Era Industri 4.0
}

\author{
Aan Nasrullah ${ }^{1}$ \\ aan.aljalil@ymail.com \\ Sekolah Tinggi Agama Islam Miftahul ‘Ula Nganjuk
}

\begin{abstract}
Absract
Millennial generations are often referred to as agents of change. currently facing challenges from social change brought about by industry 4.0. Industry 4.0 has a negative impact, namely characters that are no longer in accordance with values and norms. The industrial era

4.0 has eroded the values of human life, including the millennial generation. Technology develops independently and is increasingly separate, and leaves religion and social values far behind. Ibn Khaldun's idea of Islamic education can shape humans to have character, so that the millennial generation is able to become humans who have quality, to be able to maintain the life and existence of a highly cultured society in accordance with the flow of the times. The idea of Islamic education that is able to shape the character of the millennial generation are cognitive intelligence. (fikriyyah ma'rifiyyah), affective intelligence (khuluqiyah), psychomotor intelligence (jihadiyah), spiritual intelligence (ruuhaniyah) and social intelligence (ijtima'iyah).
\end{abstract}

Keywords: Millennial Generation, Character Education, Ibn Khladun, Industry 4.0

\section{Pendahuluan}

Generasi milenial atau generasi muda adalah sumber penggerak dan pembawa perubahan yang sering disebut sebagai agent of change (agen perubahan). Banyak literatur mengemukakan bahwa yang dimaksud dengan pemuda adalah Pertama, mereka yang berumur 10-24 tahun; Kedua, mereka yang berumur antara 15-30 tahun; Ketiga, mereka yang berumur antara 15-35 tahun; Keempat, mereka yang secara psikologis mempunyai jiwa muda dan mempunyai identitas kepemudaan. Dari pendapat diatas dapatlah dikemukakan bahwa yang dimaksud dengan pemuda adalah mereka yang berumur 10-35 tahun atau lebih, dengan catatan, yang lebih dari 35 tahun tersebut secara psikologis mempunyai jiwa kepemudaan dan mempunyai identitas kepemudaan. ${ }^{2}$

Dalam literatur lainnya generasi milenial disebut sebagai generasi $\mathrm{Y}$ yang lahir antara 1977-1998. Generasi Y di tahun 2008 berusia antara 21 hingga 29 tahun. Generasi milenial sudah berinteraksi dengan teknologi sejak lahir. Generasi ini banyak menggunakan teknologi

\footnotetext{
${ }^{1}$ Dosen Tetap STAI Miftahul 'Ula Nganjuk

2 M. Munandar Soelaeman, Ilmu Sosial Dasar: Teori dan Konsep Ilmu Sosial, (Bandung: PT. Refika Aditama, 2008), 164.
} 
komunikasi instan, seperti: e-mail, SMS (Short Message Service), instan messaging, dan media sosial seperti Facebook, Twitter, Whatsapp dan lain sebagainya, generasi ini juga menyukai game on-line. Adapun karakter dari generasi ini pada umumnya memiliki rasa percara diri, optimistis, ekspresif, bebas, dan menyukai tantangan. ${ }^{3}$

Islam sebagai agama universal yang ajaran-ajarannya sesuai dengan perubahan perdaban, memiliki pendapat tentang identitas kepemudaan atau asy-syabab yang dapat dilihat dalam ungkapan sifat dan sikap yakni: Pertama, berani merombak dan bertindak revolusioner terhadap tatanan sistem yang rusak. Kedua, memiliki standar moralitas (iman), berwawasan, bersatu, optimis dan teguh dalam pendirian serta konsisten dalam perkataan. Ketiga, seorang yang tidak berputus asa, pantang mundur sebelum cita-citanya tercapai.

Sejalan dengan pendapat tersebut, identitas kepemudaan atau generasi milenial dapat dilihat melalui pola-pola tindakannya yakni penuh dengan kreativitas disertai penanaman asasasas moral, etika, bersusila, serta berkeyakinan agama, dan mampu dijadikan barometer kehidupan berbangsa. Begitu banyak hal-hal yang menggambarkan identitas kepemudaan itu sendiri dalam ranah praktis maupun ilmiah. ${ }^{4}$

Namun, saat ini generasi milenial menghadapi tantangan dari perubahan sosial yang dibawa arus industri 4.0. perubahan arus industri 4.0 berdampak pada perubahan karakter kaum milenial, di mana industri 4.0 menjadikan masyarakat di seluruh dunia menjadi saling tergantung di semua aspek kehidupan: politik, ekonomi dan kultural. ${ }^{5}$ Dampak negatif lain dari industri 4.0 dalam hal kemajuan teknologi informasi dan komunikasi adalah semakin hilangnya etika (ethical zero). Orang bebas memilih manapun, apapun yang mereka sukai. Generasi muda saat inipun digandrungi fenomena demikian. Memilih kemudahan mengakses komunikasi dan informasi, bukan lagi untuk menambah ilmu pengetahuan, tetapi mengakses situs-situs yang merusak seperti situs berbau pornografi.

Kebudayaan telah berkembang menjadi peradaban lintas negara atau dunia tanpa batas (borderless world) sebagai buah meningkatnya komunikasi antarnegara seiring dengan teknologi komunikasi yang semakin canggih, kemajuan teknologi memiliki kecenderungan melindas nilainilai dan norma. Fenomena yang terjadi dalam masyarakat merupakan disfungsi sosial. Disfungsi

\footnotetext{
${ }^{3}$ Oktavianus, 2017 dalam R. Willay Achmad W, dkk. Potret generasi milenial pada era revolusi industri 4.0. Focus: Jurnal Pekerjaan Sosial, Vol. 2 No: 2, Desember 2019. Hal: 187 - 197

${ }^{4}$ Ibid, 170.

${ }^{5}$ Piötr Sztompka, Sosiologi Perubahan Sosial, (Jakarta: Prenada, 2008), 101.
} 
terjadi dikarenakan nilai dan norma telah mengalami kemunduran dalam menjalankan fungsinya sebagai alat yang ideal untuk mengontrol perilaku sosial masyarakat. ${ }^{6}$

Akibat menurunnya fungsi sosial dalam masyarakat, menimbulkan dampak negatif yakni karakter yang tidak lagi sesuai dengan nilai dan norma. Hal tersebut kini terlihat dalam kehidupan sehari-hari masyarakat, sejauh ini dapat dilihat dihampir semua media massa, setiap hari ada saja kasus tentang korupsi, sadisme, perampokan, pencurian, tindak anarkis, narkoba, pergaulan bebas, prostitusi, dan lain-lain ${ }^{7}$. Perilaku menyimpang tersebut semakin menjamur dari kalangan usia anak-anak hingga usia dewasa. Rusaknya moral dan karakter seharusnya membuat berbagai kalangan semakin serius untuk mengembalikan keteraturan sosial. Salah satunya adalah membina karakter individu yang sesuai dengan nilai dan norma yang baik dalam masyarakat.

Penanaman dan pembinaan karakter merupakan tugas bagi orang tua dalam pranata keluarga, institusi pendidikan, lembaga keagamaan, lingkungan sosial masyarakat hingga pemerintah. Agar degradasi moral dan karakter tidak akan sampai pada generasi penerus bangsa di era selanjutnya. Cita-cita para pendiri bangsa yang tertulis dalam pembukaan UUD 1945 akan terwujud jika kita serius mencari solusinya. Sebab bagaimanapun, generasi muda yang akan menjadi tonggak perjuangan dan penerus estafet untuk membangun dan memperbaiki peradaban bangsa ini kearah yang jauh lebih baik.

Konsep pendidikan Ibnu Khaldun mempunyai arah yang jelas yaitu mencoba membawa umat manusia untuk bisa mensosialisasikan hakikat pendidikan sosial dengan realitas yang ada di sekitarnya yang meliputi realitas yang adikuasa, material, spiritual, benda-benda, hewan dan manusia, dengan cara yang lebih baik. ${ }^{8}$ Oleh sebab itu, pembinaan karakter seharusnya menjadikan generasi muda tersebut memiliki kecerdasan. Seperti yang diungkapkan Ahmad Tarmiji dalam sebuah Jurnal :

"Menurut Ibnu Khaldun seperti disinggung dalam Muqqaddimah-nya, kendati tidak secara runut, kecerdasan manusia meliputi lima aspek yaitu aspek kognitif (fikriyyah

${ }^{6}$ Lismijar, Konsep Pendidikan Islam Dalam Perspektif Ibnu Khaldun, Jurnal Ilmiah Pereduan Vol. I, No. 01, September 2013, 15

${ }^{7} \mathrm{Ibid}, 17$

${ }^{8}$ Nashruddin, Tokoh-tokoh Pendidikan Islam di Jaman Jaya, (Jakarta: Mutiara, 1979), 15 
ma'arifiyyah), afektif (khuluqiyah), psikomotorik (jihadiyah), spiritual (ruuhaniyah), serta sosial kemasyarakatan (ijtima'iyah)". 9

Kelima aspek kecerdasan tersebut diatas merupakan kecerdasaan yang harus dimiliki oleh generasi milenial untuk memproteksi diri dari dampak negatif perkembangan zaman di era industri 4.0 dewasa ini. Pembinaan dan pembentukan kecerdasan tersebut adalah tang gung jawab dan kewajiban bagi seluruh elemen masayarakat. Orang tua dalam pranata keluarga, institusi pendidikan, institusi keagamaan, lingkungan masyarakat, sampai pada elemen dalam pemerintahan daerah dan pusat memiliki porsi masing-masing dalam melakukan tindakan serius terhadap pembinaan dan pembentukan karakter generasi penerus bangsa ini. Semua itu terjadi melalui proses pendidikan yang terus menerus dan berkesinambungan.

Ibnu Khaldun dengan pengalamannya yang luas telah mampu menghasilkan karyanya yang besar. Hal ini telah membuatnya menjadi terkenal sebagai pendidik dan pengamat yang jeli tentang realitas pendidikan di zamannya. Ia mampu membangun teori-teori pendidikan yang terkenal sebagaimana termaktub dalam kitabnya Muqaddimah. Dalam kitab ini, Ibnu Khaldun banyak mengupas permasalahan pendidikan pada suatu bab tersendiri yaitu bab keenam. ${ }^{10}$

Bila dipahami, secara implisit konsep pendidikan Islam yang digagas Ibnu Khaldun mengarah pada pembentukan karakter seseorang, yakni seseorang yang memiliki kecerdasan pada aspek kognitif (fikriyyah ma'arifiyyah), afektif (khuluqiyah), psikomotorik (jihadiyah), spiritual (ruuhaniyah), serta sosial kemasyarakatan (ijtima'iyah). Dari uraian di atas, kajian ini mencoba untuk mendeskripsikan terkait dengan pendidikan Islam yang digagas oleh Ibnu Khaldun, dan urgnesinya bagi generasi milenial pada era industri 4.0.

\section{A. Pendidikan Islam Ibnu Khladun}

Pemikiran pendidikan Islam yang diusung oleh Ibnu Khaldun yaitu al-umm al-hukmiyyah al-falsafiyyah. Konsep pendidikan yang ditawarkan memiliki pengaruh dan peran dalam pengetahuan dan peradaban yang berkembang sampai sekarang.

1. Definisi Pendidikan Islam Ibnu Khaldun

9 Ahmad Tarmiji, Meretas Jalan Sosiologi Pendidikan Ibnu Khaldun : Antara Pendidikan Karakter dan Pendidikan Nasionalisme, dalam Jurnal Komunitas Sosiologi Volume 3 No. 2 Desember 2008, (Jakarta: Jurusan Sosilogi FIS UNJ, 2008), 50-51.

${ }^{10}$ Ali Abdul Wahid, Ibnu Khaldun: Riwayat dan Karyanya, (Jakarta: Pustaka Hidayah, 1995), 157. 
Pendekatan konsep pendidikan Ibnu Khaldun adalah bahwa manusia dalam berpendidikan sangat berkaitan erat dengan dirinya, kehidupan sosial di sekitarnya serta spesialisasi yang dimiliki sehingga tercipta peradaban selanjutnya. Lebih lanjut Ibnu Khaldun menyatakan bahwa hakikat pendidikan Islam bukanlah suatu aktivitas yang semata-mata bersifat pemikiran dan perenungan yang jauh dari aspek-aspek pragmatis di dalam kehidupan, akan tetapi ilmu dan pendidikan merupakan gejala konklusif yang lahir dari terbentuknya masyarakat dan perkembangannya dalam tahapan kebudayaan. ${ }^{11}$

Pendidikan menurut Ibnu Khaldun adalah upaya mentransformasikan nilai-nilai yang diperoleh dari pengalaman untuk dapat dipertahankan eksistensi manusia dalam peradaban masyarakat. Pendidikan adalah upaya melestarikan dan mewariskan nilai-nilai yang ada dalam masyarakat agar masyarakat tersebut bisa tetap eksis. Pemikiran Ibnu Khaldun tentang pendidikan telah tertuangkan dalam karya monumentalnya yang dikenal dengan sebutan Muqaddimah. ${ }^{12}$ Ibnu Khaldun sebagai seorang filsuf muslim telah memprakarsai pemikirannya yang sangat rasional dan sungguh berpegang teguh pada logika. Corak ini menjadi pijakan dasar baginya dalam membangun konsep-konsep pendidikan. Menurutnya paling tidak ada tiga tujuan yang hendak dicapai oleh pendidikan Islam, yaitu peningkatan kecerdasan dan kemampuan berpikir, peningkatan segi kemasyarakatan manusia, peningkatan segi kerohanian manusia. Sehingga diharapkan pendidikan Islam mampu menciptakan manusia yang siap menghadapi berbagai fenomena sosial yang ada di sekitarnya.

Dari pendapatnya ini dapat diketahui bahwa pendidikan menurut Ibnu Khaldun mempunyai pengertian yang cukup luas. Pendidikan bukan hanya merupakan proses belajar mengajar yang dibatasi oleh empat dinding, tetapi pendidikan adalah suatu proses, di mana manusia secara sadar menangkap, menyerap, dan menghayati peristiwa-peristiwa alam sepanjang zaman. Konsep pendidikan ini sesuai dengan konsep pendidikan nasional, yakni proses pembelajaran sepanjang masa.

2. Urgensi dan Tujuan Pendidikan Karakter Ibnu Khaldun

\footnotetext{
${ }^{11}$ Nashruddin, Tokoh-tokoh Pendidikan Islam di Jaman Jaya, (Jakarta: Mutiara, 1979), 15

12 Ali Wardi, Ibnu Khaldun dan Pola Pemikiran Islam, Alih Bahasa Osman Ralibi, (Jakarta: Pustaka Firdaus, 1989), 89.
} 
Dalam bidang pendidikan, Ibnu Khaldun berpendapat bahwa pendidikan atau ilmu dan mengajar merupakan suatu kemestian dalam membangun masyarakat manusia. Hal ini dapat terlihat pada pandangannya mengenai urgensi pendidikan, yaitu: ${ }^{13}$

a. Memeberikan kesempatan kepada pikiran untuk aktif dan bekerja, karena aktifitas penting bagi terbukanya pikiran dan kematangan individu yang pada gilirannya kematangan individu ini bermanfaat bagi masyarakat.

b. Memperoleh berbagai ilmu pengetahuan, sebagai alat yang membantu manusia agar dapat hidup dengan baik, dalam rangka terwujudnya masyarakat maju dan berbudaya.

c. Memperoleh lapangan pekerjaan yang dapat digunakan untuk mencari penghidupan yang layak dan mencukupi kebutuan hidup.

Sedangkan tujuan pendidikan Islam menurut Ibnu Khaldun bertitik tolak dari tujuan hidup manusia. Sedangkan tujuan hidup manusia dapat dilihat dari segi siapa manusia, dari mana dan mau kemana. Alur pemikiran Ibnu Khaldun mengenai manusia bertitik tolak dari sudut pandang sosiologisnya, yaitu bagaimana manusia bisa mempertahankan eksistensi manusia dan berkebudayaan tinggi. Apabila manusia sebagai makhluk sosial itu berkembang untuk melestarikan dan mempertinggi tingkat kebudayaannya, maka berarti manusia itu makhluk yang berkebudayaan baik moral maupun material. Di antara berbagai insting manusia adalah adanya kecenderungan untuk mempertahankan segala apa yang dimilikinya termasuk kebudayaannya. Oleh karena itu, maka manusia perlu melakukan transformasi dan trasmisi (pemindahan dan penyaluran) kebudayaannya kepada generasi yang akan menggantikannya kelak dikemudian hari. ${ }^{14}$

Anak akan menjadi dewasa dan menjadi generasi penerus masa depan. Pada pundaknyalah diserahkan tanah air, karena anak sekarang adalah orang dewasa kelak, dan apa yang ditanamkannya sekarang akan dipetik buahnya (hasilnya) kemudian. Untuk itu, para orang tua, guru dan para ahli pendidikan hendaknya memperhatikan anak-anaknya dan para muridnya, agar mereka menjadi pemikir ulung dan praktisi cekatan di masa yang akan datang. Juga, hendaknya diberikan berbagai macam ilmu pengetahuan kepada mereka untuk dididik secara sempurna baik di lingkungan keluarga, sekolah maupun di masyarakat.

\footnotetext{
${ }^{13}$ Abudin Nata, Filsafat Pendidikan Islam, Cet. III, (Jakarta: Gama Media Pratama, 2005), 35.

${ }^{14}$ Nur Uhbiyati, Nur, Ilmu Pendidikan Islam, Cet. II, (Bandung: Pustaka Setia, 1997), 97.
} 
Dari uraian di atas, maka generasi milenial harus memiliki kualitas, untuk dapat mempertahankan hidup dan eksistensi masyarakat yang berkebudayaan tinggi sesuai dengan alur perkembangan zaman. Dengan demikian dapat dijelaskan bahwa tujuan pendidikan menurut Ibnu Khaldun adalah sebagai berikut: Pertama, untuk mengembangkan intelektualitas peserta didik. Ia memandang bahwa aktivitas ini sangat penting bagi terbukanya pikiran dan kematangan individu. Kedua, memperoleh ilmu pengetahuan sebagai alat untuk membantunya hidup dengan baik di dalam masyarakat maju dan berbudaya. Sebagaimana yang telah dijelaskan sebelumnya, bahwa manusia berbeda dengan makhluk lainnya karena kemampuannya untuk berpikir.

Dari sini dapat diketahui bahwa ada dua aspek penting yang dapat dicapai oleh kemampuan akal, yaitu aspek sosial dan spiritual. Keduanya dapat dimiliki oleh manusia melalui proses aktualisasi dari generasi ke generasi. Dengan kata lain, bahwa manusia tersebut akan mencari orang-orang yang sejak pertama kali sudah memiliki pengetahuan. Dengan harapan bahwa dia akan memberikan pengetahuan (transfer of knowledge) tersebut kepada dirinya. Intinya bahwa urgensi pendidikan menurut Ibnu Khaldun yaitu: memberikan kesempatan kepada pikiran untuk aktif dan bekerja, memperoleh berbagai ilmu pengetahuan dan memperoleh lapangan pekerjaan yang dapat digunakan untuk mencari penghidupan yang layak.

\section{B. Pentingnya Pendidkan Karakter}

Sebagaimana tujuan pendidikan nasional yang tertuang pada Undang-undang SISDIKNAS No. 20 Tahun 2003 pasal 3 yakni, untuk mengembangkan potensi peserta didik agar menjadi manusia yang beriman dan bertakwa kepada Tuhan Yang Maha Esa, berakhlak mulia, sehat, berilmu, cakap, kreatif, mandiri dan menjadi warga negara yang demokratis serta bertanggung jawab. ${ }^{15}$ Sebenarnya amanat undang-undang sistem pendidikan nasional bertujuan membentuk insan Indonesia yang cerdas dan berkepribadian atau berkarakter sehingga melahirkan generasi bangsa yang tumbuh dan berkembang daya karakter yang bernafaskan nilai-nilai luhur bangsa

\footnotetext{
${ }^{15}$ Anas Salahudin, dkk, Pendidikan Karakter: Pendidikan Berbasis Agama dan Budaya, (Pustaka Setia: Bandung, 2013), 41.
} 
dan agama. ${ }^{16}$ Salah satu upaya untuk merealisasikannya adalah dengan cara memperkuat jati diri dan karakter bangsa melalui pendidikan.

Menurut Kemendiknas yang dikutip dari Agus Wibowo, karakter merupakan ciri khas seseorang atau kelompok orang yang mengandung nilai, kemampuan, kapasitas moral, dan ketegaran dalam menghadapi kesulitan dan tantangan. ${ }^{17}$ Selain itu karakter menurut Helen Douglas yang dikutip dari Muchlas Samawi dan Hadiyanto dikatakan bahwa karakter tidak diwariskan, tetapi sesuatu yang dibangun secara berkesinambungan hari demi hari melalui pikiran dan perbuatan, pikiran demi pikiran, tindakan demi tindakan. Sehingga karakter dimaknai sebagai cara berfikir dan bertingkahlaku yang khas tiap individu untuk hidup dan bekerjasama, baik dalam lingkup keluarga, masyarakat, bangsa dan Negara. ${ }^{18}$ Dari pengertian ini dapat dipahami bahwa karakter anak didik merupakan kualitas atau kekuatan mental atau moral, akhlak atau budi pekerti individu yang merupakan kepribadian khusus yang harus melekat sebagai pendorong dan penggerak dalam melakukan sesuatu.

Dalam terminologi agama Islam, karakter dapat disepadankan dengan akhlak, terutama dalam kosakata akhlakul karimah atau akhlak yang mulia, yang dalam pendidikan di Indonesia dulu semakna dengan istilah budi pekerti. Betapa pentingnya akhlak atau karakter sehingga Nabi Muhammad SAW di utus untuk menyempurnakan akhlak yang mulia dalam haditsnya beliau menegaskan :“aku diutus (Allah) untuk menyempurnakan keluhuran budi pekerti (akhlak)”19

Dilihat dari pengertian karakter dan akhlak tidak banyak memiliki perbedaan. Keduanya didefinisikan sebagai suatu tindakan yang terjadi tanpa ada lagi pemikiran, karena sudah tertanam dalam pikiran dan dengan kata lain keduanya dapat disebut sebagai kebiasaan. Hal ini berpijak pada pendapat Abdul Mujib dan Dian Andayani apapun sebutannya karakter ini adalah sifat batin manusia yang mempengaruhi segenap pikiran dan perbuatannya. ${ }^{20}$

Berbicara mengenai karakter, sesungguhnya karakter merupakan pilar penting bagi kemajuan bangsa. Karakter yang tertanam kuat dari setiap individu akan menimbulkan kehidupan berbangsa dan bernegara. Karena kesuksesan tidak ditentukan semata-mata oleh

\footnotetext{
16 Ibid, 42.

17 Agus Wibowo, Pendidikan Karakter Berbasis Sastra, (Yogyakarta: Pustaka Pelajar, 2013), 14.

18 Muchlas Samawi, dan Hadiyanto, Konsep dan Model Pendidikan Karakter, (Bandung: PT Remaja Rosda Karya, 2012), 41-42

${ }^{19}$ Malik Bin Annas, Al-Muwaththa ${ }^{\mathrm{ee}}$, (Beirut: Dar Al-Kotob, Al-ilmiyah, 2009), 504.

${ }^{20}$ Abdul Mujib dan Dian Andayan, Pendidikan Karakter Perspektif Islam, (Bandung: PT Remaja Rosdakarya, 2012), 12 .
} 
pengetahuan dan kemampuan teknis (hard skill), tetapi oleh kemampuan mengelola diri dan orang lain (soft skill). ${ }^{21}$ Hal inilah yang menjadi salah satu pentingya pendidikan karakter untuk melahirkan generasi milenial yang kokoh untuk menyikapi menghadapi perkembangan zaman. Hal ini juga yang menyebabkan alasan perlunya dilakukan pembenahan dalam bidang pendidikan kita, karena pendidikan di Indonesia saat ini lebih menitikberatkan pada pengembangan intelektual atau kognitif semata (hard skill). Padahal pendidikan juga harus berbasis pada pengembangan soft skill (interaksi sosial) hal ini penting untuk membentuk karakter generasi milenial sehingga mampu bersaing dan beretika.

Menurut Undang-Undang Republik Indonesia Nomor 20 tahun 2003 tentang Sikdiknas pasal 3 dijelaskan bahwa pendidikan karakter adalah mengembangkan kemampuan dan membentuk watak serta peradaban bangsa yang bermartabat dalam rangka mencerdaskan kehidupan bangsa, bertujuan untuk berkembangnya potensi peserta didik agar menjadi manusia yang beriman dan bertakwa kepada Tuhan Yang Maha Esa, berakhlak mulia, sehat, berilmu, cakap, kreatif, mandiri dan menjadi warga negara yang demokratis serta bertanggung jawab. ${ }^{22}$

Dari pemaparan konsep pendidikan, karakter dan akhlak, maka dapat dipahami bahwa pendidikan karakter adalah pendidikan untuk membentuk sifat atau karakter baik agar tertanam dan mengakar pada jiwa anak. Pendidikan karakter adalah pendidikan yang tidak hanya mengedepankan aspek kognitif atau intelektual semata, akan tetapi lebih berorientasi pada aspek pembinaan dan pengembangan potensi yang dimiliki peserta didik secara keseluruhan melalui pembiasaan sifat-sifat dan sikap baik yaitu berupa nilai-nilai karakter baik.

Dalam implementasinya pendidikan karakter pada umumnya diintegrasikan dalam pembelajaran di sekolah. Namun pelaksanaan dan pengembangan pendidikan karakter di sekolah dibagi dalam empat pilar, yaitu kegiatan pembelajaran di kelas, kegiatan keseharian dalam bentuk budaya sekolah (school cultural), kegiatan kokurikuler atau ekstrakurikuler, serta kegiatan keseharian di rumah dan di masyarakat. ${ }^{23}$ Sampai disini dapat dipahami betapa pentingnya pendidkan karakter bagi generasi milenial dalam menghadapi perkembangan teknologi informasi era industri 4.0

${ }^{21}$ Abdul Mujib dan Dian Andayan, Pendidikan Karakter Perspektif, ...... 12

${ }^{22}$ Undang-Undang Nomor 20 Tahun 2003, Sistem Pendidikan Nasional, pasal 3, ayat (1)

${ }^{23}$ Muchlas Samawi, dan Hadiyanto, Konsep dan Model Pendidikan Karakter, (Bandung: PT Remaja Rosda Karya, 2012), 112 


\section{Generasi Milenial di Era Industri 4.0}

Era industri 4.0 menekankan kehidupan generasi milenial pada pemanfaatan teknologi dalam aktivitas sebagai makhluk individu maupun sosial, sehingga teknologi informasi juga mengalami perkembangan sesuai dengan kebutuhan manusia pada umumnya. Perkembangan dari teknologi akan memberikan kebermanfaatan kepada setiap generasi, terutama generasi yang mampu beradaptasi dan mampu mengendalikan teknologi. Perilaku serta kebiasaan generasi milenial yang berusia 18-40 tahun itu mempunyai tingkat antusiasme terhadap penggunaan teknologi cukup tinggi, hal ini dapat mempengaruhi terhadap sikap dan perilakunya, hasil sebuah penelitian dampak teknologi mempunyai dua pengaruh, pertama pengaruh postif yaitu memberikan manusia kemudahan untuk melakukan interaksi, mencari informasi lebih mudah, sedangkan yang kedua pengaruh negatif, manusia akan menjadi perilaku yang egois, serba instan dan interkasi terhadap lingkungan sekitar menjadi cukup buruk.

Bila diperhatkan, era industri 4.0 menjadikan generasi milenial cenderung untuk:

a. Memanfaatkan teknologi IoT, AI, Smart Machines, Knowledge Management, dan Smart Web dalam konektivitas kerja.

b. Menekankan pada bagaimana cara orang berkomunikasi dengan mesin atau orang lain melalui Intelligent Machine yang tersedia.

c. Memiliki kekuatan untnuk melakukan multitasking melalui berbagai jenis media otomatis dan platform komputasi.

d. Menekankan bahwa pekerjaan di era ini sudah bukan lagi sekadar single-job per jam, melainkan merupakan proses yang selalu berjalan dengan proses lain atau sebagai medium ke prosedur yang lain.

e. Menekankan pada pergerakan bebas dari satu proses ke proses lainnya dan memerlukan lebih sedikit protokol untuk menyelesaikan pekerjaan.

f. Mempertimbangkan rekayasa keberlanjutan di tengah-tengah teknologi progresif yang dikerahkan secara material dengan memastikan pelestarian alam dan ekologi masih dalam kondisi baik. 
Diakui atau tidak adanya Era industri 4.0 telah menggerus nilai-nlai kehidupan manusia termasuk generasi milenia. Nilai-nilai yang mulai tergerus akibat tranformasi industri 4.0 adalah sebagai berikut: ${ }^{24}$

a. Nilai Kultural. Nilai kultural adalah nilai yang berhubungan dengan budaya, karakteristik lingkungan sosial dan masyarakat. Pendidikan dap menolong siswa untuk melihat nilai-nilai kultural sosial secara sistematis dengan cara mengembangkan keseimbangan yang sehat antara sikap terbuka (openness) dan tidak mudah percaya (skepticism).

b. Nilai Yuridis Formal. Nilai Yuridis formal adalah nilai yang berkaitan dengan aspek politik, hukum dan ideologi. Nilai sosial politik suatu bahan ajar merupakan kandungan nilai yang dapat memberikan petunjuk kepada manusia untuk bersikap dan berperilaku sosial yang baik ataupun berpolitik yang baik dalam kehidupannya.

c. Nilai Religius. Mempertahankan nilai-nilai tersebut merupakan tantangan terberat dalam menghadapi revolusi industri 4.0. Perkembagan jaman menuntut manusia lebih kreatif karena pada dasarnya jaman tidak bisa dilawan. Revolusi industri 4.0. banyak menggunakan jasaa mesin dibandingkan manusia. Tetapi ada hal penting yang membedakan mesin dengan manusia yaitu dari segi nilai kemanusiaan yang tidak dimiliki oleh mesin. Penanaman nilai inilah yang perlu diperkuat untuk mengangkat harkat dan martabat bangsa khususnya di dunia pendidiakan.

Pendapat lain mengatakan, menjelang akhir abad XX, kemajuan ilmu pengetahuan dan teknologi semakin pesat sehingga terjadi teknologisasi kehidupan dan penghidupan. ${ }^{25}$ Teknologi berkembang sendiri dan makin terpisah, serta jauh meninggalkan agama dan nilai-nilai sosial. Oleh karena itu, harus ada upaya untuk memfilter dampak negatif dari pemanfaatn teknologi, revolusi Industri 4.0 memberikan dampak besar bagi kehidupan generasi milenal dan juga mempengaruhi keberfungsian sosialnya, hal yang disayangkan tidak sedikit kaum milenal di kehidupan nyata, berjuang untuk mempertahankan eksistensinya di media sosial dengan menanggalkan etika dan nilai-nilai sosial. Disinilah diperlukannya suatu pendidikan karakter untuk generasi muda, agar dalam era Industri 4.0 ini mereka tidak kehilangan jati diri dan tidak menanggalkan nilai-nilai kemanusiaan dalam bermasyarakat.

${ }^{24}$ Dimas Indianto, Pendidikan Agama Islam dalam Revolusi Industri 4.0, PROSIDING SEMINAR NASIONAL PRODI PAI UMP TAHUN 2019 ISBN : 978-602-6697-31-8

${ }^{25}$ Jacob, 1988 dalam Banu Prasetyo dan Umi Trisyanti, Prosiding SEMATEKSOS 3 "Strategi Pembangunan Nasional MenghadapiRevolusiIndustri 4.0" 


\section{Urgensi Pendidikan Karakter Prespektif Ibnu Khaldun bagi Kaum Milenial}

Sebagaimana yang dijelaskan sebelumnya bahwa, perkembangan teknologi yang dibawa oleh arus industri 4.0, membawa banyak manfaat memudahkan manusia dalam aktivitas rutinitas hariannya, seperti lebih mudah berkomunikasi dengan adanya teknologi informasi, lebih mudah dalam kegiatan ekonomi karena adanya teknologi informasi, namun disisi lain, dampak negatif tidak dapat dihindari, oleh karena itu generasi milenial sebagai generasi penerus hendaknya memiliki karakter atau kepribadian yang dapat beradaptasi dengan perubahan zaman.

Gagasan Ibnu Khaldun terkait dengan pendidikan Islam yang dapat membentuk manusia memiliki karakter, sehingga genarasi milenial mampu menjadi manusia-manusia yang memiliki kualitas, untuk dapat mempertahankan hidup dan eksistensi masyarakat yang berkebudayaan tinggi sesuai dengan alur perkembangan zaman. Penulis berpendapat, bahwa gagasan pendidikakn Islam yang mampu membentuk karakter generasi milenial adalah kecerdasan kognitif (fikriyyah ma'rifiyyah), afektif (khuluqiyah), psikomotorik (jihadiyah), spiritual (ruuhaniyah), dan sosial kemasyarakatan (ijtima'iyah).

Pertama, Kecerdasan kognitif. Gagasan Ibnu Khaldun mengenai kecerdasan kognitif (fikriyyah ma'rifiyyah) bertumpu pada kekuatan pikiran manusia. Menurut Ibnu Khaldun kemampuan berpikir manusia merupakan sumber dari segala kesempurnaan dan segala puncak kemuliaan dan ketinggian manusia dari makhluk Tuhan lainnya. Dalam Muqaddimah Ibnu Khaldun menerangkan hirarki pemikiran manusia yang pada dasarnya bertitik tolak pada rasa batiniah dan lahiriah yang akhirnya membentuk kekuatan jiwa dan kekuatan pikiran. Bahwa karakter kognitif dapat menjadikan generasi milenial mampu menghadapi perubahan zaman dengan tetap memegang teguh ajaran Islam, hal ini mengindikasikan bahwa pengetahuan mampu menjadikan generasi milenial memiliki prinsip hidup, termasuk dalam mengahadapi perubahan sosial di era industri 4.0.

Kedua, Kecerdasan afektif (khuluqiyah). Kecerdasan yang kedua ini dimaksudkan untuk mengimbangi dari karakter kognitif, apalah arti sebuah pengetahuan yang luas tanpa diimbangi dengan akhlak yang baik. Hal ini sama dengan jika kaum milenial memiliki hardskill tapi tidak memiliki softskill. Kecerdasan khuluqiyah untuk menciptakan generasi milenial yang memiliki akhalqul karimah, akhalqul karimah atau akhlak terpuji adalah suatu aturan atau norma yang mengatur hubungan antar sesama manusia dengan Tuhan dan alam semesta. Akhlaqul karimah merupakan salah satu manifestasi keimanan terhadap Allah Subhanahu wa Ta'ala. Menurut Ibnu 
Khaldun memiliki Kecerdasan afektif (khuluqiyah), akan menempatkan kepekaan manusia sebagai guidance, memandu dalam meraih kesuksesan dalam kehidupan. Kecerdasan ini bertumpu pada nilai moralitas atau akhlak (khuluqiyah).

Ketiga, Kecerdasan psikomotorik (jihadiyah). Kecerdasan psikomotorik bertujuan untuk mengembangkan ketrampilan generasi milenial, pengembangan psikomotorik memiliki peranan penting teradap kemandirian generasi milenial Menurut Ibnu Khaldun pengajaran ilmu pengetahuan adalah keahlian. Keahlian tergantung pada mutu contoh yang ditirunya. Dan baiknya keahlian yang diperoleh melalui proses pembelajaran bergantung pada guru dan metode yang digunakannya dalam proses pembelajaran. Cara pandang Ibnu Khaldun tersebut pada hakikatnya secara tersirat mengandung pengertian bahwa pengajaran, atau pendidikan dalam arti luas harus dapat menekankan dan mengembangkan aspek psikomotorik pada setiap peserta didik.

Keahlian tersebut bertujuan agar generasi milenial mampu mewujudkan hidup mandiri sekaligus berguna bagi lingkungan masyarakat. Lebih lanjut dalam Muqaddimah-nya Ibnu Khaldun membagi keahlian atau keterampilan ( $k$ kill) tersebut dalam dua kategori, yaitu keahlian yang sederhana dan kompleks. Keahlian tersebut diharapkan dapat membantu manusia untuk hidup dengan baik dalam masyarakat maju dan beradab. Keahlian -keahlian di zaman Ibnu khaldun tersebut jauh lebih sederhana dibandingkan keahlian-keahlian yang ada dewasa ini. Namun demikian substansi pemikirannya telah memperlihatkan kepada kita sebuah cara pandang yang modern di zamannya.

Keempat, Kecerdasan spiritual (ruuhaniyah). Ibnu Khaldun memiliki pandangan mengenai kecerdasan spiritual (ruhiyah) yang merupakan fitrah manusia. Oleh karena itu, kecerdasan spiritual harus dikembangkan dan ditanamkan kepada peserta didik (generasi milenial) sebagai pengajaran utama. Esensi nilai-nilai keagamaan (Spiritual) tersebut sangat penting dipelajari dan dikaji disamping mengkaji ilmu-ilmu lainnya. Kehancuran suatu negara, masyarakat, ataupun secara individu menurutnya dapat disebabkan oleh lemahnya nilai-nilai spiritual yang ditanamkan. Demikian halnya dengan generasi milenial, jika tidak memiliki kecerdasan spiritual maka akan mudah terbawa arus negatif dari Industri 4.0.

Kelima, Kecerdasan sosial kemasyarakatan (ijtima'iyah). Menurut Ibnu khaldun selain kecerdasan afektif (khuluqiyah), kecerdasan sosial pun mengarah pada pentingnya akhlakul karimah. Sebagai makhluk sosial, generasi milenial sudah seharusnya memahami hakikat diri 
dan lingkungan dalam proses perubahan yang menyertainya. Dengan memiliki kecerdasan sosial masyarakat tersebut diharapkan terlahir generasi milenial yang memiliki kesadaran akan jati dirinya sebagai makhluk sosial yang membutuhkan orang lain, teknologi tidak akan mampu menyelesaikan semua permasalahan yang dhadapi oleh generasi milenial. Dengan pemahaman bahwa manusia adalah makhluk sosial, maka generasi milenial memiliki jiwajiwa sosial, peduli dengan lingkungan sekitar, memiliki kesadaran sosial dan kesalehan sosial.

Berbicara mengenai karakter, sesungguhnya karakter merupakan pilar penting bagi kemajuan bangsa. Karakter yang tertanam kuat dari setiap individu akan menimbulkan kehidupan berbangsa dan bernegara. Karena kesuksesan tidak ditentukan semata-mata oleh pengetahuan dan kemampuan teknis (hard skill). Sehingga kelima kecerdasan di atas, seyoyanya mendapat perhatian dari segenap elemen masyarakat, institusi pendidikan sampai dengan pemerintah.

\section{E. Penutup}

Generasi milenial yang sering disebut sebagai agent of change (agen perubahan). saat ini menghadapi tantangan dari perubahan sosial yang dibawa arus industri 4.0. di mana industri 4.0 menimbulkan dampak negatif yakni karakter yang tidak lagi sesuai dengan nilai dan norma. Penanaman dan pembinaan karakter merupakan tugas bagi orang tua dalam pranata keluarga, institusi pendidikan, lembaga keagamaan, lingkungan sosial masyarakat hingga pemerintah. Agar degradasi moral dan karakter tidak akan sampai pada generasi penerus bangsa di era selanjutnya. Cita-cita para pendiri bangsa yang tertulis dalam pembukaan UUD 1945 akan terwujud jika kita serius mencari solusinya.

Amanat undang-undang sistem pendidikan nasional bertujuan membentuk insan Indonesia yang cerdas dan berkepribadian atau berkarakter sehingga melahirkan generasi bangsa yang tumbuh dan berkembang daya karakter yang bernafaskan nilai-nilai luhur bangsa dan agama. Salah satu upaya untuk merealisasikannya adalah dengan cara memperkuat jati diri dan karakter bangsa melalui pendidikan. Karakter merupakan pilar penting bagi kemajuan bangsa. Karakter yang tertanam kuat dari setiap individu akan menimbulkan kehidupan berbangsa dan bernegara. Sehingga dapat dipahami betapa pentingnya pendidkan karakter bagi generasi milenial dalam menghadapi perkembangan teknologi informasi era industri 4.0 
Diakui atau tidak Era industri 4.0 telah menggerus nilai-nlai kehidupan manusia termasuk generasi milenial. Teknologi berkembang sendiri dan makin terpisah, serta jauh meninggalkan agama dan nilai-nilai sosial. Gagasan Ibnu Khaldun terkait dengan pendidikan Islam yang dapat membentuk manusia memiliki karakter, sehingga genarasi milenial mampu menjadi manusiamanusia yang memiliki kualitas, untuk dapat mempertahankan hidup dan eksistensi masyarakat yang berkebudayaan tinggi sesuai dengan alur perkembangan zaman.

Gagasan pendidikakn Islam yang mampu membentuk karakter generasi milenial adalah Pertama, Kecerdasan kognitif. (fikriyyah ma'rifiyyah) kecerdasan kognitif menjadikan generasi milenial mampu menghadapi perubahan zaman dengan tetap memegang teguh ajaran Islam. Kedua, Kecerdasan afektif (khuluqiyah). Kecerdasan khuluqiyah untuk menciptakan generasi milenial yang memiliki akhalqul karimah yang akan menempatkan kepekaan manusia sebagai guidance, memandu dalam meraih kesuksesan dalam kehidupan. Ketiga, Kecerdasan psikomotorik (jihadiyah). Kecerdasan ini mengembangkan ketrampilan generasi milenial, dan memiliki peranan penting teradap kemandirian generasi milenial. Keempat, Kecerdasan spiritual (ruuhaniyah). Esensi nilai-nilai keagamaan (Spiritual) sangat penting dipelajari dan dikaji disamping mengkaji ilmu-ilmu lainnya. Kehancuran suatu negara, masyarakat, ataupun secara individu menurutnya dapat disebabkan oleh lemahnya nilai-nilai spiritual yang ditanamkan. Kelima, Kecerdasan sosial kemasyarakatan (ijtima’iyah). Sebagai makhluk sosial, generasi milenial sudah seharusnya memahami hakikat diri dan lingkungan dalam proses perubahan yang menyertainya. Dengan memiliki kecerdasan sosial generasi milenial yang memiliki kesadaran akan jati dirinya sebagai makhluk sosial yang membutuhkan orang lain. Dengan pemahaman bahwa manusia adalah makhluk sosial, maka generasi milenial memiliki jiwa-jiwa sosial, peduli dengan lingkungan sekitar, memiliki kesadaran sosial dan kesalehan sosial.

Karakter, sesungguhnya karakter merupakan pilar penting bagi kemajuan bangsa. Karakter yang tertanam kuat dari setiap individu akan menimbulkan kehidupan berbangsa dan bernegara. Karena kesuksesan tidak ditentukan semata-mata oleh pengetahuan dan kemampuan teknis (hard skill). Sehingga kelima kecerdasan di atas, seyoyanya mendapat perhatian dari segenap elemen masyarakat, institusi pendidikan sampai dengan pemerintah.

\section{Daftar Pustaka}


Tafhim Al-IImi : Jurnal Pendidikan dan Pemikiran Islam Terakreditasi Nasional SK No : 148/M/KPT/2020
ISSN: 2252-4924, e-ISSN: 2579-7182

Volume 12, No. 1 September 2020

Annas, Malik. 2009. Al-Muwaththa. Beirut: Dar Al-Kotob, Al-ilmiyah

Indianto, Dimas. Pendidikan Agama Islam dalam Revolusi Industri 4.0, PROSIDING SEMINAR NASIONAL PRODI PAI UMP TAHUN 2019 ISBN : 978-602-6697-31-8

Khasali, R.2018. Strawberry Generation. Jakarta: Mizan.

Lismijar, Konsep Pendidikan Islam Dalam Perspektif Ibnu Khaldun, Jurnal Ilmiah Pereduan Vol. I, No. 01, September 2013

Nata, Abudin. 2005. Filsafat Pendidikan Islam, Cet. III. Jakarta: Gama Media Pratama.

Nashruddin. 1979. Tokoh-tokoh Pendidikan Islam di Jaman Jaya. Jakarta: Mutiara.

Palupi, W. 2016. Gambaran Remaja Indonesia Di Masa Datang. At-Tahdzib: Jurnal Studi Islam Dan Muamalah, 2(2), 12-18. Retrieved from http://ejournal.kopertais4.or.id/mataraman/index.php/tahdzib/article/view/1856

Prasetyo, Banu dan Trisyanti, Umi. Prosiding SEMATEKSOS 3 "Strategi Pembangunan Nasional MenghadapiRevolusiIndustri 4.0"

R. Willay Achmad W, dkk. Potret generasi milenial pada era revolusi industri 4.0. Focus: Jurnal Pekerjaan Sosial, Vol. 2 No: 2, Desember 2019. Hal: 187 - 197

Soelaeman, M. Munandar. 2008. Ilmu Sosial Dasar: Teori dan Konsep Ilmu Sosial. Bandung: PT. Refika Aditama.

Sztompka, P. 2008. Sosiologi Perubahan Sosial. Jakarta: Prenada.

Salahudin, Anas. Dkk. 2013. Pendidikan Karakter: Pendidikan Berbasis Agama dan Budaya. Pustaka Setia: Bandung

Samawi, Muchlas dan Hadiyanto. 2012. Konsep dan Model Pendidikan Karakter. Bandung: PT Remaja Rosda Karya.

Tarmiji, Ahmad. Meretas Jalan Sosiologi Pendidikan Ibnu Khaldun : Antara Pendidikan Karakter dan Pendidikan Nasionalisme, dalam Jurnal Komunitas Sosiologi Volume 3 No. 2 Desember 2008, (Jakarta: Jurusan Sosilogi FIS UNJ, 2008)

Uhbiyati, Nur. 1997. Ilmu Pendidikan Islam, Cet. II. Bandung: Pustaka Setia.

Undang-Undang Nomor 20 Tahun 2003, Sistem Pendidikan Nasional, pasal 3, ayat (1)

Wardi, Ali. 1989. Ibnu Khaldun dan Pola Pemikiran Islam, Alih Bahasa Osman Ralibi. Jakarta: Pustaka Firdaus. 
Tafhim Al-'Ilmi : Jurnal Pendidikan dan Pemikiran Islam

Terakreditasi Nasional SK No : 148/M/KPT/2020
ISSN: 2252-4924, e-ISSN: 2579-7182

Volume 12, No. 1 September 2020

Wibowo, Agus.2013. Pendidikan Karakter Berbasis Sastra. Yogyakarta: Pustaka Pelajar. 